\title{
Regiones, régions, regions, everywhere.... But what about the people? Why Regions \& Cohesion
}

\author{
Harlan Koff and Carmen Maganda
}

Université du Luxembourg

Since the end of the Cold War in 1990, "regions" and "governance" have become prominent themes in the social sciences and they have often accompanied each other in both political and academic circles. During this historical period, regions have developed in many ways, including the proliferation and deepening of regional integration schemes, including among others, the enlargement of the European Union (EU), the establishment of the North American Free Trade Agreement, the passage of the Organization of African Unity to the African Union, and the transformation of the Andean Pact into the Andean Community. While world regions were being established at the supranational level, sub-national regions also began to take form. The 1990s witnessed the development of regional economies, regional identities, regionalist ideologies, political parties, and social movements. In many cases, these transformations could not be contained by national boundaries. The notion of "borders" has recently been replaced by "border regions" as these areas have become accepted as socially constructed territories that transcend political and geographic delineations.

Because of the increasingly complex economic, political, and social relationships found in sub-national, transnational and supranational regions, the notion of "government" has recently been replaced with "governance." Previously, institutions were charged with simply managing territories. Today, governance generally refers to authorities' ability to steer, alone or in cooperation with other actors, economy and society. However, it must be mentioned that the concept of "governance" remains widely disputed. How can effective governance strategies be established when conceptualized definitions/desired outcomes remain undefined?

In fact, rich academic debates on "governance" have recently blossomed, yet no universally accepted approaches have evolved. For this rea- 
son, "good governance" is often defined in terms of economic growth and political/social stability, especially when associated with regions. For example, supranational regions were generally created (or developed in the case of the EU) in neoliberal contexts with the objective of improving competitiveness in the global economy. Governance at the sub-national and transnational levels has also often focused on the economic well-being of these communities.

The importance of growth and stability at the macro level to the conceptualization of governance makes one question why social consequences are being ignored in these debates. Are territories serving their citizens and do citizens serve the needs of expanding territorial markets?

Thus far, studies of the social impact of regional integration have often centered on "social cohesion." This term, however, has become politically charged in certain territories, and cross-regional studies have demonstrated that its definitions are regionally bounded (Koff, 2009). In the United States and Canada, social cohesion often refers to issues related to identity and ethnic relations. In Latin America, it focuses on anti-poverty strategies. In Europe, social cohesion debates concentrate on welfare and rights. One common theme in all these discussions, however, is the definition of social cohesion as a policy tool. Attention to the human and environmental impacts of regional integration has in fact been very limited.

Regions \& Cohesion openly asks, "what about the people?" How can we move citizens to the center of debates on regionalization processes at the supranational, transnational, and sub-national levels? "Governance" is not synonymous with "democracy." Just because regions are competitive at the macro level does not mean that all participants benefit from regionalization. For this reason, Regions $\mathcal{E}$ Cohesion, the journal of the Consortium for Comparative Research on Regional Integration and Social Cohesion (RISC), is pleased to provide a multilingual (English, French, and Spanish) and interdisciplinary forum for the discussion of the human and environmental impacts of regional integration as well as governance processes. The editorial board welcomes contributions from scholars and practitioners on related themes. In addition to traditional scientific articles, Regions $\mathcal{E}$ Cohesion is proud to publish analytical, policy-related contributions from both academics and practitioners in its "Leadership Forum."

This first issue of Regions \& Cohesion asserts the journal's scientific mission and normative character by presenting an array of topics relevant to the journal's purpose: human security, state-building and democratization, regional integration processes, continental histories, human rights, foreign policies, metropolitan governance, development aid, regional goods, immigration, social marginalization, and access to public services. Rather than performing the impossible task of limiting the first number of an 
interdisciplinary and cross-regional journal to a single, special issue, the editors instead contacted recognized scholars from different continents and asked that they propose article subjects linked to the publication's scientific mission. We are proud to receive and publish the five scientific articles, two "leadership" analyses, and the book review/essay included in this inaugural issue.

Regions $\mathcal{E}$ Cohesion is a team effort, and the editors wish to thank those who have supported this intellectual project during this initial stage, including: the contributors to this first issue, the distinguished members of our international editorial board, the article reviewers, our translators, and the editorial team at the University of Luxembourg. Special thanks also go to our colleagues at Berghahn Journals, and our sponsors, the Direction de la Coopération au Développement du Grand Duché de Luxembourg (especially its director, Mr. Marc Bichler), and the Fonds National de la Recherche de Luxembourg.

\section{References}

Koff, H. (2009). Social cohesion in Europe and the Americas: Power, time and space. Brussels: P.I.E.-Peter Lang. 